\title{
Relative abundance of Antillean manatees in the Pantanos de Centla Biosphere Reserve in the coastal plain of Tabasco, Mexico
}

\section{Abundancia relativa del manatí antillano en la Reserva de la Biosfera Pantanos de Centla en la planicie costera de Tabasco, México}

\author{
Gissel Puc-Carrasco ${ }^{1}$, León David Olivera-Gómez ${ }^{1 *}$, Stefan Arriaga-Hernández², \\ Darwin Jiménez-Domínguez ${ }^{1}$ \\ ${ }^{1}$ División Académica de Ciencias Biológicas, Universidad Juárez Autónoma de Tabasco, km 0.5 Carretera \\ Villahermosa-Cárdenas, Entronque a Bosques de Saloya, CP 86039, Villahermosa, Tabasco, México. \\ 2 Facultad de Ciencias, Universidad Nacional Autónoma de México, Av. Universidad 3000, Circuito Exterior S/N, \\ Delegación Coyoacán, Ciudad Universitaria, CP 04510, Ciudad de México, México.
}

* Corresponding author. E-mail: leon_olivera@yahoo.com.mx

\begin{abstract}
Abundance estimates for the Antillean manatee, Trichechus manatus manatus, in the southern Gulf of Mexico are based on interviews, mortality reports, and opportunistic sightings. The lack of quantitative data is explained by the complexity of hard-to-access fluviallake systems, low water transparency, and the elusive behavior of manatees. Side-scan sonar is a promissory tool to detect and count manatees in fluvial systems. The Pantanos de Centla Biosphere Reserve (PCBR), in the coastal plain of Tabasco (Mexico), could play a key role in the regional conservation of manatees, but it is under constant pressure, especially from the oil and gas industry, and it is important to generate quantitative data for this area. The objective of this study was to quantify the relative abundance of manatees at 4 selected sites within PCBR and at 2 reference sites outside the reserve using side-scan sonar, as a basis for the long-term monitoring of the species and to determine the importance of the reserve for regional manatee conservation. We conducted 5 to 7 boat surveys on 10-km line transects along selected water courses and recorded 63 manatee sightings. Manatees occurred at all sampling sites and abundance increased upriver. The site with the highest mean abundance $(5.17 \pm 1.9$ manatees $/ 10 \mathrm{~km}$ ) was located at the southeastern end of PCBR. There was statistical difference among sites. The southeastern portion of Tabasco is a key region for manatee conservation and management in Mexico. PCBR is a key regional feature but it is necessary to define protection strategies within and beyond its southern limits.
\end{abstract}

Key words: conservation, freshwater ecosystems, quantitative assessment, side-scan sonar, Trichechus manatus manatus.

RESUMEN. Los registros de abundancia del manatí antillano, Trichechus manatus manatus, en el golfo de México provienen en su mayoría de entrevistas, casos de mortalidad y avistamientos oportunistas. La falta de datos cuantitativos se explica por la complejidad y el difícil acceso a los sistemas fluviolagunares, la baja transparencia del agua y la conducta evasiva de los manatíes. El sonar de barrido lateral es una herramienta promisoria para detectar y contar manatíes en ambientes fluviales. La Reserva de la Biosfera Pantanos de Centla (RBPC), en la planicie costera de Tabasco (México), puede representar un mecanismo importante de conservación regional del manatí. La RBPC está en constante presión de desarrollo, especialmente por parte de la industria de los hidrocarburos, lo que resalta la importancia de generar datos cuantitativos y comparativos. El objetivo de este trabajo fue cuantificar la abundancia relativa de manatíes en 4 sitios seleccionados dentro de la RBPC y en 2 sitios de referencia fuera de la reserva utilizando un sonar de barrido lateral, como base para el monitoreo a largo plazo de la especie y para evaluar la importancia de la RBPC como un mecanismo de conservación regional del manatí. Se realizaron de 5 a 7 recorridos en lancha a lo largo de $10 \mathrm{~km}$ lineales en cursos de agua selectos, y se registraron 63 avistamientos de manatíes. Los manatíes estuvieron presentes en todos los sitios y la abundancia se incrementó río arriba. El sitio con mayor abundancia promedio (5.17 \pm 1.9 manatíes/10 km) se localizó en el límite sureste de la RBPC. La porción sureste de Tabasco es una región clave para la conservación y manejo del manatí en México. La RBPC es clave en esta región, pero es necesario definir estrategias de protección dentro y fuera de su límite sureste.

Palabras clave: conservación, ecosistemas dulceacuícolas, cuantificación, sonar de barrido lateral, Trichechus manatus manatus.

\section{INTRODUCTION}

The International Union for the Conservation of Nature (IUCN) enlisted the West Indian manatee (Trichechus manatus) as a vulnerable species because of the historic reduction of its populations and current threats (Deutsch et al. 2008). Moreover, the Antillean subspecies (Trichechus manatus manatus) is considered endangered (Self-Sullivan

\section{INTRODUCCIÓN}

La Unión Internacional para la Conservación de la Naturaleza (IUCN) considera al manatí del Caribe (Trichechus manatus) como una especie vulnerable debido a la reducción histórica de sus poblaciones y a las amenazas actuales (Deutsch et al. 2008). Más aún, la subespecie antillana (Trichechus manatus manatus) se considera en peligro de 
and Mignucci-Giannoni 2008). This subspecies is found from Mexico to Brazil, including the Greater Antilles and Trinidad and Tobago (Lefebvre et al. 2001). It primarily inhabits turbid and structurally complex freshwater environments (Marsh et al. 2012), where abundance estimation is precluded.

The typical methods for counting manatees are boat and aerial surveys (Aragones et al. 2012, Reynolds et al. 2012). These methods yield uncertain results in turbid or dark water. A novel method to detect and count manatees in these environments is using small side-scan sonar devices (GonzalezSocoloske et al. 2009). Side-scan sonar is an efficient tool to detect manatees as far as $30 \mathrm{~m}$ from each side of the boat, depending on bottom type, width of waterways, depth, and presence of other fauna (Gonzalez-Socoloske et al. 2009, Gonzalez-Socoloske and Olivera-Gómez 2012).

In the coastal plains of the southern Gulf of Mexico, large rivers form extensive wetland areas with a seasonal floodpulse dynamics (Moreno-Casasola et al. 2012). One of the largest manatee populations in Mexico inhabits these shallow riverine environments (Marsh et al. 2012), but quantitative assessments have not been made in this area, only in Quintana Roo (Morales-Vela et al. 2000). All the information we have about manatees in the Gulf of Mexico comes from interviews, strandings, and opportunistic sightings of this species (Colmenero and Hoz 1986, Arriaga and Contreras 1993), or from recent studies in particular areas (PabloRodríguez and Olivera-Gómez 2012, Jiménez-Domínguez and Olivera-Gómez 2014).

The coastal plain region of the state of Tabasco is a manatee hotspot in the southern Gulf of Mexico (Colmenero and Hoz 1986, Arriaga and Contreras 1993). However, current threats for the species are increasing and are linked to development pressure of several human activities and industries, including oil and gas extraction. Tabasco is one of the states with the most extensive onshore oil fields in Mexico (INEGI 2011). The Pantanos de Centla Biosphere Reserve (PCBR) is a large wetland protection area in Mexico and is thought to play an important role in the conservation of many plant and animal species, the manatee being one of them (INE 2000), but its real contribution is unknown. The objective of this study was to survey the relative abundance of manatees at selected sites inside PCBR and other reference sites outside the reserve, to visualize spatial patterns in abundance, and to start a regional long-term monitoring of the species. In this survey we used side-scan sonar units and followed standardized procedures.

\section{MATERIAL AND METHODS}

\section{Study area}

This study was conducted within PCBR $\left(17^{\circ} 57^{\prime} 53^{\prime \prime}\right.$ to $18^{\circ} 39^{\prime} 03^{\prime \prime} \mathrm{N}, 92^{\circ} 06^{\prime} 49^{\prime \prime}$ to $92^{\circ} 47^{\prime} 58^{\prime \prime} \mathrm{W}$ ) and at 2 reference sites, one to the northeast $\left(18^{\circ} 22^{\prime}\right.$ to $18^{\circ} 24^{\prime} 22^{\prime \prime} \mathrm{N}, 92^{\circ} 55^{\prime}$ to extinción (Self-Sullivan y Mignucci-Giannoni 2008). Esta subespecie se ubica desde México hasta Brasil, incluyendo las Antillas Mayores y Trinidad y Tobago (Lefebvre et al. 2001). Su hábitat incluye principalmente ambientes de agua dulce turbios y con alta complejidad estructural (Marsh et al. 2012), donde no es fácil estimar la abundancia con los métodos tradicionales.

Los métodos típicos para el conteo de manatíes se desarrollan a partir de encuentros visuales desde embarcaciones o avionetas (Aragones et al. 2012, Reynolds et al. 2012). Estos métodos generan resultados inciertos en aguas turbias u oscuras. Un nuevo método para detectar y contar los manatíes en estos entornos es el uso de pequeños dispositivos de sonar de barrido lateral (Gonzalez-Socoloske et al. 2009). El sonar de barrido lateral es una herramienta eficaz para detectar los manatíes hasta distancias de $30 \mathrm{~m}$ de cada lado de la embarcación, bajo ciertas condiciones de tipo de fondo, ancho de los cursos de agua, profundidad y presencia de otra fauna (Gonzalez-Socoloske et al. 2009, Gonzalez-Socoloske y Olivera-Gómez 2012).

En las llanuras costeras del sur del golfo de México, grandes ríos forman extensas zonas de humedales con una dinámica de pulsos de inundación estacional (MorenoCasasola et al. 2012). En estos ambientes fluviales habita una de las más grandes poblaciones de manatíes en México (Marsh et al. 2012), pero a diferencia de la población costera de Quintana Roo (Morales-Vela et al. 2000), no existen aproximaciones cuantitativas de la abundancia de manatíes. Todo lo que se sabe acerca de los manatíes en el golfo de México proviene de entrevistas, varamientos y avistamientos oportunistas de esta especie (Colmenero y Hoz 1986, Arriaga y Contreras 1993), o de estudios recientes en áreas particulares (Pablo-Rodríguez y Olivera-Gómez 2012, JiménezDomínguez y Olivera-Gómez 2014).

La región de la llanura costera del estado de Tabasco es un punto importante de distribución de manatíes en el sur del golfo de México (Colmenero y Hoz 1986, Contreras y Arriaga 1993). Sin embargo, las amenazas actuales para la especie están aumentando, y están vinculadas a la presión del desarrollo de varias actividades humanas e industriales, incluida la exploración y producción de petróleo y gas. En este sentido, Tabasco es uno de los estados de México con los campos más extensos en tierra de extracción de hidrocarburos (INEGI 2011). La Reserva de la Biosfera Pantanos de Centla (RBPC) es un gran humedal natural protegido de México y se piensa que desempeña un papel importante en la conservación de diversos animales y plantas, entre ellos el manatí (INE 2000), pero su contribución real es desconocida. El objetivo de este estudio fue cuantificar la abundancia relativa de los manatíes en sitios seleccionados dentro de la RBPC y otros puntos de referencia fuera de la reserva para visualizar los patrones espaciales de abundancia y para iniciar un monitoreo regional a largo plazo de la especie. Para esto, se utilizaron unidades de sonar de barrido lateral siguiendo procedimientos estandarizados. 
$\left.92^{\circ} 59^{\prime} 30^{\prime \prime} \mathrm{W}\right)$ and the other to the southeast $\left(17^{\circ} 46^{\prime} 30^{\prime \prime}\right.$ to $17^{\circ} 45^{\prime} 45^{\prime \prime} \mathrm{N}, 91^{\circ} 25^{\prime} 30^{\prime \prime}$ to $91^{\circ} 21^{\prime} \mathrm{W}$ ) of this reserve. PCBR extends over parts of the municipalities of Centla, Jonuta, and Macuspana in Tabasco, and over a portion of Palizada in southern Campeche (Fig. 1), covering an area of 302,706 ha (CONANP 2001). The northwestern and northeastern limits of PCBR are the city of Frontera and the Gulf of Mexico at the mouth of the San Pedro/San Pablo River, respectively. The southern limit of PCBR is the Bitzales River (Romero et al. 2000).

PCBR is located in the "Southern Gulf Coastal Plain" physiographic province and in the "Plains and Swamps of Tabasco" subprovince. The altitude in the terrain varies from -1 to $7 \mathrm{~m}$ above mean sea level (INE 2000). Climate is subhumid with summer rains, annual average temperature of $25^{\circ} \mathrm{C}$, and annual rainfall of $1,600 \mathrm{~mm}$. Four geomorphic systems of plains can be found in PCBR: alluvial, marshfreshwater lake, coastal barrier, and lagoon (Romero et al. 2000). Hydrophilic plant communities dominate the ecosystems in PCBR, together with tropical semi-deciduous forest

\section{MATERIALES Y MÉTODOS}

\section{Área de estudio}

Este estudio se realizó dentro de la RBPC $\left(17^{\circ} 57^{\prime} 53^{\prime \prime}\right.$ a $18^{\circ} 39^{\prime} 03^{\prime \prime} \mathrm{N}, 92^{\circ} 06^{\prime} 49^{\prime \prime}$ a $92^{\circ} 47^{\prime} 58^{\prime \prime}$ W) y en otros 2 sitios de referencia hacia el noreste $\left(18^{\circ} 22^{\prime}\right.$ a $18^{\circ} 24^{\prime} 22^{\prime \prime} \mathrm{N}, 9^{\circ} 55^{\prime}$ a $\left.92^{\circ} 59^{\prime} 30^{\prime \prime} \mathrm{W}\right)$ y el sureste de la misma $\left(17^{\circ} 46^{\prime} 30^{\prime \prime}\right.$ a $17^{\circ} 45^{\prime} 45^{\prime \prime} \mathrm{N}, 9^{\circ} 25^{\prime} 30^{\prime \prime}$ a $\left.91^{\circ} 21^{\prime} \mathrm{W}\right)$. La RBPC cubre una superficie de 302,706 ha (CONANP 2001), que abarca parte de los municipios de Centla, Jonuta y Macuspana en Tabasco y una porción del municipio Palizada en el sur de Campeche (Fig. 1). Los límites noroeste y noreste de la RBPC son, respectivamente, la ciudad de Frontera y el golfo de México en la desembocadura del río San Pedro y San Pablo. El límite sur de la RBPC es el río Bitzales (Romero et al. 2000).

La RBPC se ubica en la provincia fisiográfica Llanura Costera del Golfo Sur y en la subprovincia Llanuras y Pantanos Tabasqueños. La altitud de los terrenos varía de -1 a $7 \mathrm{~m}$ sobre el nivel medio del mar (INE 2000). El clima en la

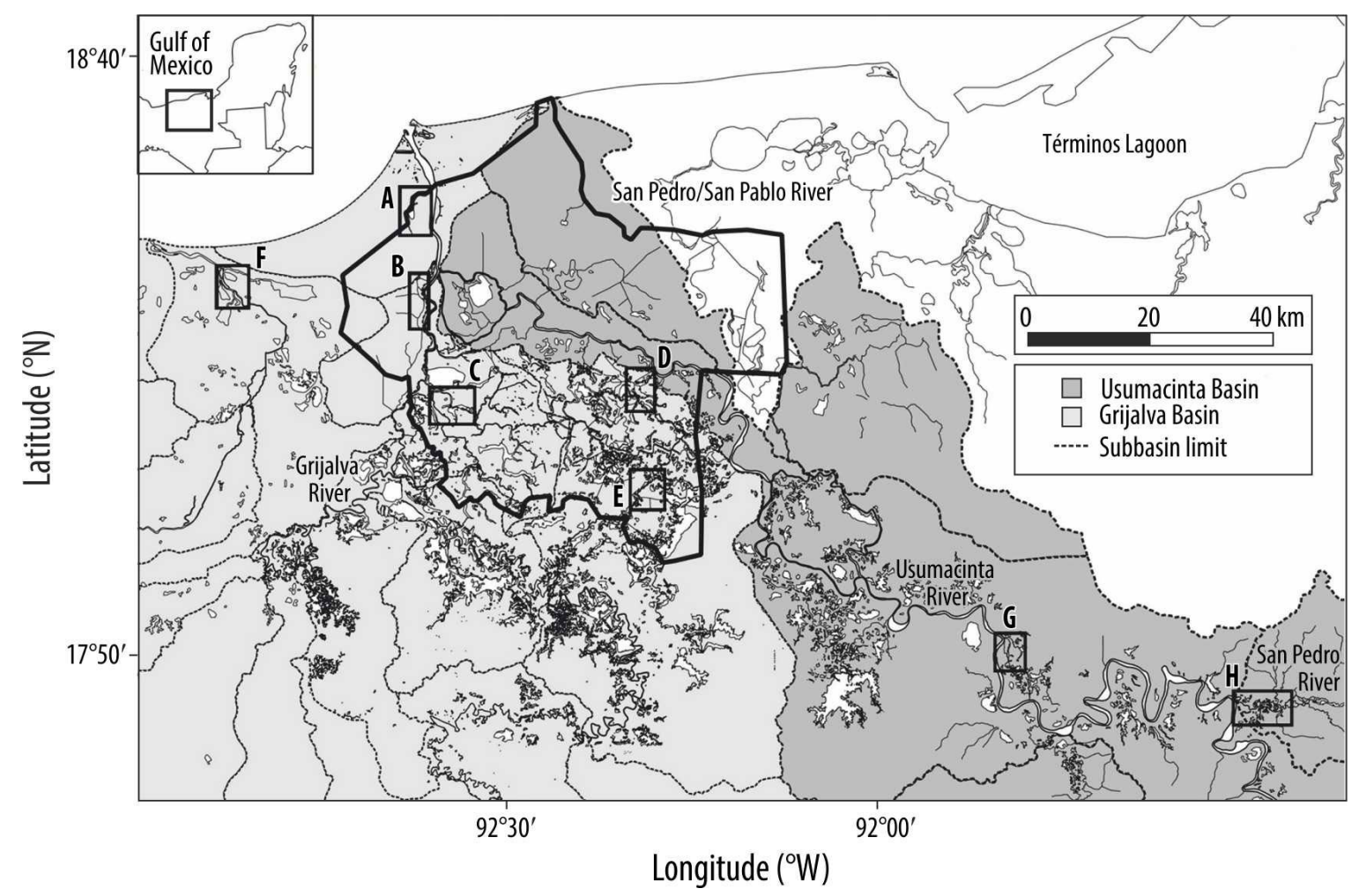

Figure 1. Study area in the central and eastern portions of Tabasco, Mexico. The continuous bold line indicates the limits of the Pantanos de Centla Biosphere Reserve. Small boxes indicate the sites sampled in this study (2012-2013): (A) El Coco, (B) Tabasquillo, (D) San José, (E) Bitzales, (F) González, and (H) San Pedro. Sites C and G were initially sampled but excluded because their depth profiles were not comparable with the other sites.

Figura 1. Área de estudio en las porciones centro y este de Tabasco, México. Los límites de la Reserva de la Biosfera de Pantanos de Centla se muestran con una línea gruesa y continua. Los cuadros indican los sitios de muestreo de este estudio (2012-2013): (A) El Coco, (B) Tabasquillo, (D) San José, (E) Bitzales, (F) González y (H) San Pedro. Los sitios C y G se muestrearon al principio, pero se descartaron por tener perfiles de profundidad no comparables con el resto de los sitios. 
dominated by Bucidas bucera L, low evergreen forest of Haematoxylum campechianum, bushes of Dalbergia brownei, palm communities of Acoelorraphe wrightii and Sabal mexicana, and mangrove forest (Guadarrama-Olivera and Ortiz-Gil 2000, Zenteno et al. 2010). The more coastal sites may have patches of Vallisneria americana (Novelo and Ramos 2005). Several main rivers flow through the reserve (Grijalva, Usumacinta, Palizada, San Pedro/San Pablo, and Bitzales), as well as several secondary rivers (Chilapa, Puxcatán, Naranjos, and Palomillal) and many other smaller streams and channels, most of them artificial for access to oil extraction facilities. In total, $925 \mathrm{~km}$ are covered by rivers. The lentic systems comprise about 110 freshwater lakes that cover an area of 13,665 ha, mainly in the central and southern areas where $84 \%$ are located.

These rivers are avenues for manatee movements among sites. The intensity of manatee movements in this region is still unknown, but the sites we chose for this study are associated with lake systems that could promote the temporal establishment of manatees, precluding high rates of movement among sites. Manatees can presumably move from sites all year round but connection among sites is more probable during the rainy months due to higher water level along water courses.

The 2 reference sites outside PCBR are a segment of the González River and a site at the confluence of the San Pedro and Usumacinta Rivers. Both sites are waterways used mainly by artisanal fishermen to travel among towns. Human population is higher in the González River area but terrestrial roads are well established and boat travel is not heavy.

\section{Boat surveys and detection method}

From August to December 2012 and from February to June 2013 we surveyed 4 sites within PCBR (El Coco, Tabasquillo, San José, and Bitzales) and 2 reference sites outside the reserve (González River and San Pedro River). The distance between sites ensured low probability of the short-term movement of manatees from one site to another, except between El Coco and Tabasquillo, separated by $14 \mathrm{~km}$. Reference sites were included to determine the relative importance of PCBR with respect to other adjacent areas, which are not under any protected status, where a high frequency of manatee sightings has been reported (Colmenero and Hoz 1986, Arriaga and Contreras 1993), especially in southeastern Tabasco. We conducted surveys between 10:00 and 15:00 h on an 8-m-long boat, powered by a 15-25 HP outboard engine, along a segment of $10 \mathrm{~km}$ of waterways. Boat speed was $7.5-10.0 \mathrm{~km} / \mathrm{h}$. Selected waterways were $<70 \mathrm{~m}$ wide and 2 to $5 \mathrm{~m}$ deep. We conducted 5 to 7 boat surveys per site. To detect manatees we used a Humminbird 687c SI or 898c SI side-scan sonar unit (Eufraula, AL, USA). The detection width of the sonar was set to $20 \mathrm{~m}$ on each side of the boat, and all manatees detected by the sonar were counted. The crew consisted of 2 sonar operators and 1 visual reserva es subhúmedo, con lluvias en verano, una temperatura media de $25^{\circ} \mathrm{C}$ y precipitación anual de $1,600 \mathrm{~mm}$. En la RBPC se encuentran 4 sistemas geomórficos de llanura: aluvial, palustre y lagunar de agua dulce, de cordón litoral y lagunar costera (Romero et al. 2000). Las comunidades de plantas hidrófilas dominan los ecosistemas en la RBPC, junto con la selva mediana dominada por Bucidas bucera L, una selva baja subperenifolia de Haematoxylum campechianum, matorrales de Dalbergia brownei, comunidades de palmas de Acoelorraphe wrightii y Sabal mexicana, y bosque de manglar (Guadarrama-Olivera y Ortiz-Gil 2000, Zenteno et al. 2010). Los sitios más costeros pueden tener manchones de Vallisneria americana (Novelo y Ramos 2005). Varios ríos fluyen a través de la reserva (Grijalva, Usumacinta, Palizada, San Pedro y San Pablo, y Bitzales), así como varios ríos secundarios (Chilapa, Puxcatán, Naranjos y Palomillal) y muchos otros arroyos y canales más pequeños, muchos de ellos artificiales de acceso a pozos petroleros lacustres. Juntos, los cauces de los ríos suman alrededor de $925 \mathrm{~km}$. Los sistemas lénticos están constituidos por unos 110 cuerpos de agua dulce que cubren una superficie de 13,665 ha, y las zonas centro y sur concentran el $84 \%$ de las lagunas.

Estos ríos constituyen vías de desplazamiento para los manatíes entre los distintos sitios, aunque la intensidad de los movimientos no ha sido estudiada hasta el momento. Los sitios elegidos para este estudio están asociados a sistemas lagunares que promueven la permanencia de manatíes en un área. En teoría, los manatíes pueden desplazarse de un sitio a otro todo el año; sin embargo, en la época de las avenidas lluviosas la conexión entre sitios puede ser más efectiva debido al aumento en el nivel de los cursos de agua.

Los 2 sitios de referencia fuera de la RBPC fueron un segmento del río González y la zona de confluencia de los ríos San Pedro y Usumacinta. Los 2 sitios son vías fluviales utilizadas principalmente por pescadores artesanales para desplazarse. La densidad humana es relativamente mayor en las comunidades adyacentes al río González (INEGI 2011); sin embargo, las vías de comunicación terrestre son más importantes en esta zona y la presión por embarcaciones sobre las vías fluviales no es alta.

\section{Reconocimiento desde la embarcación y método de detección}

Se realizaron recorridos de agosto a diciembre de 2012 y de febrero a junio de 2013 en 4 sitios dentro de la RBPC (El Coco, Tabasquillo, San José y Bitzales) y 2 sitios de referencia fuera de ésta (río González y río San Pedro). La distancia entre los sitios hace poco probable el movimiento de individuos a corto plazo, excepto entre El Coco y Tabasquillo, que están separados por unos $14 \mathrm{~km}$. Los sitios de referencia se incluyeron para destacar la importancia relativa de la reserva con respecto a otros sitios del estado que no están cobijados por un área natural protegida, donde se ha registrado una alta frecuencia de observaciones de manatíes (Colmenero y Hoz 
observer. When the sonar operators registered a manatee we repeatedly passed over the location to confirm it. As confirmation criteria we used visual contact at the surface or changes in orientation or position of the object sighted on the sonar screen. Screen capture was recorded for each sighting for posterior examination.

\section{Correction factor}

Because of the small number of counts recorded at most sites, we opportunistically used the visit with the highest number of manatees to compute a correction factor, which was not applied to counts but as an indicator of the fraction of manatees not counted due to perception bias. In March 2013, we found a group of 23 manatees in Bitzales River at a point outside the established segment. To estimate a correction factor, we passed 12 times over a 3-km segment (where the 23 manatees were dispersed), recording repeated counts. We used 2 independent sonar units mounted on the same boat. Each sonar operator registered the minute and second of each sighting. Sonar operators had similar experience in manatee discrimination and more than $50 \mathrm{~h}$ of training. With these data we estimated a correction factor (CF) based on perception bias using the Petersen mark-recapture procedure, following Marsh and Sinclair (1989), using the next formulae:

$$
\begin{gathered}
C F=\frac{\left(S_{1}+b\right)\left(S_{2}+b\right)}{b\left(S_{1}+S_{2}+b\right)} \\
C V_{C F}=\frac{\left(S_{1}+S_{2}\right)}{\left(S_{1}+S_{2}+b\right) \sqrt{\left(S_{1} S_{2}\right) / b\left(S_{1}+b\right)\left(S_{2}+b\right)}}
\end{gathered}
$$

where $S_{1}$ and $S_{2}$ are the number of sighting made by either the first or the second counter, $b$ is the number of sightings made by both counters, and $C V$ is the coefficient of variation.

\section{Statistical analysis}

We computed relative abundance as number of manatees in a $10-\mathrm{km}$ segment. Differences in relative abundance among sites were analyzed using the Kruskal-Wallis test, followed by a post hoc analysis (Siegel and Castellan 1995). For descriptive purposes, the distribution of counts for each site was estimated generating 10,000 bootstrap samples from observed data (Good 2006). Statistical analyses were performed in R v3.01 (2013, R Foundation for Statistical Computing).

\section{RESULTS}

The relative abundance of manatees at the different sites varied from 0 to 10 manatees in a $10-\mathrm{km}$ transect (Table 1 , Fig. 2). We registered low counts at sites in the northern portion of the reserve (sites A and B in Figs. 1 and 3) and higher
1986, Arriaga y Contreras 1993), sobre todo el sureste de Tabasco. Se realizaron entre 5 y 7 recorridos por sitio. Los recorridos se realizaron entre las 10:00 y 15:00 h en una embarcación de $8 \mathrm{~m}$ de eslora con un motor fuera de borda de 15-25 HP, a lo largo de un transecto de $10 \mathrm{~km}$ de cursos de agua. La velocidad de la embarcación fue de $7.5-10.0 \mathrm{~km} / \mathrm{h}$. Los cursos de agua seleccionados tuvieron un ancho menor que $70 \mathrm{~m}$ y profundidades de 2 a $5 \mathrm{~m}$. Para detectar a los manatíes, se utilizó una unidad de sonar de barrido lateral Humminbird 687c SI ó 898c SI (Eufraula, AL, EUA). El ancho de detección del sonar se fijó a 20 m hacia cada lado de la embarcación, y se contaron todos los manatíes detectados por el sonar. La tripulación consistió en 2 operadores de sonar con experiencia y 1 observador visual. Cuando se detectaba un manatí con el sonar, se pasaba la embarcación varias veces sobre el punto de detección para confirmar el avistamiento. Como criterio de confirmación se utilizaron el contacto visual en superficie y los cambios en la orientación o posición del objeto avistado en la pantalla del sonar. Se capturaron imágenes de la pantalla correspondientes a cada avistamiento.

\section{Factor de corrección}

Debido al reducido número de registros en la mayoría de los sitios, utilizamos oportunísticamente la visita con el mayor conteo de manatíes para calcular un factor de corrección, el cual no fue aplicado a los conteos sino que se utilizó como un indicador de la fracción no contada debido al sesgo de percepción. En marzo de 2013, encontramos un grupo de 23 manatíes en el río Bitzales en un sitio fuera del transecto establecido. Para estimar un factor de corrección, pasamos 12 veces sobre un segmento de $3 \mathrm{~km}$, donde los 23 manatíes se dispersaron, y se registraron conteos repetidos. Se utilizaron 2 unidades de sonar independientes montadas en el mismo bote. Cada uno de los 2 operadores de sonar registró el minuto y segundo de cada observación. Los operadores del sonar tenían experiencia similar, más de 50 h de trabajo, en la discriminación de los manatíes en la pantalla del sonar. Con esos datos se estimó el factor de corrección (FC) debido al sesgo por percepción mediante el procedimiento de captura-recaptura de Petersen, de acuerdo con Marsh y Sinclair (1989), utilizando las siguientes fórmulas:

$$
\begin{gathered}
F C=\frac{\left(S_{1}+b\right)\left(S_{2}+b\right)}{b\left(S_{1}+S_{2}+b\right)} \\
C V_{F C}=\frac{\left(S_{1}+S_{2}\right)}{\left(S_{1}+S_{2}+b\right) \sqrt{\left(S_{1} S_{2}\right) / b\left(S_{1}+b\right)\left(S_{2}+b\right)}}
\end{gathered}
$$

donde $S_{1}$ y $S_{2}$ corresponden al numero de avistamientos registrados por el primero o el segundo observador únicamente, $b$ es el número de avistamientos registrados por ambos observadores y $C V$ es el coeficiente de variación. 

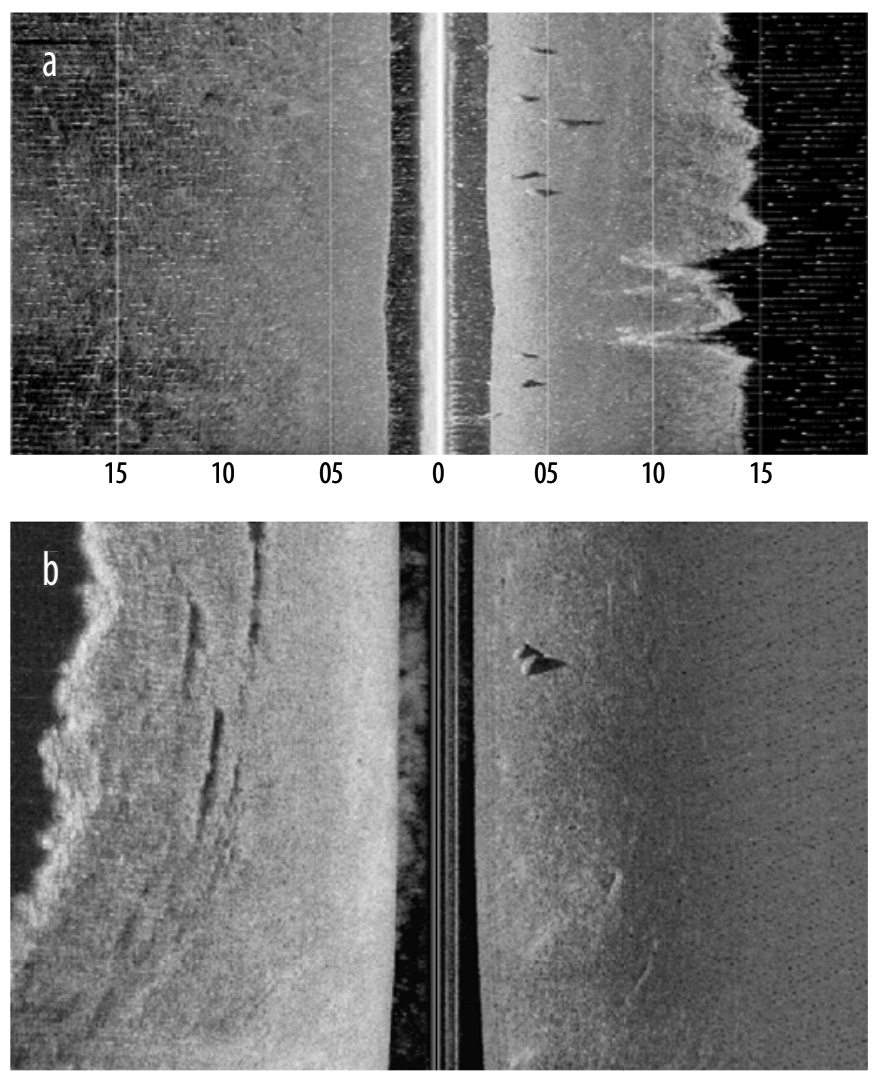

Figure 2. Example of side-scan sonar images. (a) Fragment of a video with several manatees recorded in Bitzales. (b) Screenshot of mother and calf sighted in San Pedro.

Figura 2. Ejemplo de imágenes capturadas por el sonar de barrido lateral. (a) Fragmento de un video con varios manatíes grabado en Bitzales. (b) Captura de pantalla de una madre y su cría en San Pedro.

counts in the southern part (sites D and E in Figs. 1 and 3). The sites outside the reserve (sites $\mathrm{F}$ and $\mathrm{H}$ in Figs. 1 and 3) showed the same pattern. We found differences in relative abundance among sites (Kruskal-Wallis $W=14.53$, d.f. $=5$, $P=0.012$ ). The post hoc analysis showed 3 groups of sites (Fig. 3). The site with highest relative abundance was Bitzales (mean and standard error of $5.17 \pm 1.9$ manatees/ $10 \mathrm{~km}$ ); at this site we sighted another 27 manatees outside the established segment. However, Bitzales was not statistically different from San Pedro and San José and even from El Coco. The abundance was similar at San Pedro and San José $(2.4 \pm 0.75$ and $2.0 \pm 0.68$ manatees $/ 10 \mathrm{~km})$ and lower at El Coco $(1.4 \pm 0.40$ manatees $/ 10 \mathrm{~km})$. Tabasquillo and González differed from the rest of the sites, except in the case of El Coco and Tabasquillo. Tabasquillo and González were characterized by low relative abundance (lower than 1 manatee $/ 10 \mathrm{~km}$ ). The estimated mean correction factor was $1.2 \pm 0.17$. The coefficient of variation of the correction factor had a mean of $0.21 \pm 0.03$.

\section{Análisis estadístico}

La abundancia relativa se calculó como el número de manatíes en $10 \mathrm{~km}$ de transecto. La diferencia relativa entre los sitios se analizó con una prueba de Kruskal-Wallis, seguido de un procedimiento post hoc (Siegel y Castellan 1995). Para propósitos descriptivos y comparativos, la distribución empírica de los conteos se estimó generando 10,000 muestras bootstrap de los datos originales de cada sitio (Good 2006). Los análisis estadísticos se realizaron en el programa R v3.01 (2013, R Foundation for Statistical Computing).

\section{RESUltados}

La abundancia relativa de manatíes en los diferentes sitios varió entre 0 y 10 manatíes en $10 \mathrm{~km}$ de transecto (Tabla 1 , Fig. 2). Se registraron conteos bajos en los sitios al norte de la reserva (sitios A y B en Figs. 1 y 3) y conteos más numerosos en la parte sur (sitios D y E en Figs. 1 y 3). Los sitios fuera de la reserva (F y H en Figs. 1 y 3) tuvieron el mismo patrón. Al comparar la abundancia relativa de manatíes, se encontró diferencia significativa entre los sitios ( $W$ de Kruskal-Wallis $=14.53$, g.l. $=5, P=0.012$ ). Con el análisis de comparaciones múltiples se encontraron 3 grupos de sitios (Fig. 3). El sitio con mayor abundancia relativa fue Bitzales (media y error estándar de $5.17 \pm 1.79$ manatíes/10 km); en este sitio observamos otros 27 animales fuera del segmento establecido. Sin embargo, Bitzales no fue significativamente distinto de San Pedro y San José e incluso de El Coco. San Pedro y San José tuvieron abundancias similares entre sí $(2.4 \pm 0.75$ y $2.0 \pm 0.68$ manatíes $/ 10 \mathrm{~km})$, y en El Coco la abundancia fue baja $(1.40 \pm 0.40$ manatíes $/ 10 \mathrm{~km})$. Tabasquillo y González se diferenciaron del resto de los sitios y se caracterizaron por tener abundancias muy bajas (menores que 1 manatí en $10 \mathrm{~km}$ de transecto). La media estimada para el factor de corrección fue de $1.2 \pm 0.17$, y el coeficiente de variación del factor de corrección fue de $0.21 \pm 0.03$.

\section{DisCUSIÓN}

González, Tabasquillo y El Coco, los sitios más costeros, presentaron bajas abundancias relativas, lo que coincide con la ocurrencia ocasional reportada por Colmenero y Hoz (1986). El río González es el sitio más costero de este estudio y se localiza fuera de la RBPC. Estudios previos consideraron este sitio como un área con presencia ocasional de manatíes (Colmenero y Hoz 1986) y como un área con potencial de alta abundancia debido a las características del hábitat (Arriaga y Contreras 1993). Aunque en el presente estudio se registró la menor abundancia relativa en este sitio, algunos pescadores de la zona reportaron que vieron manatíes en repetidas ocasiones en el tiempo que duró el estudio, pero los vieron en el río principal y no en los cursos de agua 
Table 1. Number of surveys $(n)$ and number of manatees detected by side-scan sonar in 10-km segments along selected waterways within and outside the Pantanos de Centla Biosphere Reserve, Tabasco, Mexico (2012-2013).

Tabla 1. Número de recorridos (n) y número de manatíes detectados con el sonar de barrido lateral en segmentos de 10 km a lo largo de cursos de agua dentro y fuera de la Reserva de la Biosfera de Pantanos de Centla, Tabasco, México (2012-2013).

\begin{tabular}{|c|c|c|c|c|c|c|}
\hline Site & $n$ & $\begin{array}{l}\text { Number of } \\
\text { manatees }\end{array}$ & $\begin{array}{c}\text { Mean density } \\
\text { (manatees/10 km) }\end{array}$ & $\begin{array}{l}\text { Standard } \\
\text { deviation }\end{array}$ & $\begin{array}{l}\text { Standard } \\
\text { error }\end{array}$ & Range \\
\hline Bitzales* & 6 & 31 & 5.17 & 4.67 & 1.90 & $0-10$ \\
\hline El Coco & 5 & 7 & 1.40 & 0.89 & 0.40 & $1-3$ \\
\hline Tabasquillo & 6 & 2 & 0.33 & 0.52 & 0.21 & $0-1$ \\
\hline
\end{tabular}

* Another 27 manatees were sighted outside the established segments; they were not used in the analysis.

\section{DISCUSSION}

González, Tabasquillo, and El Coco, the most coastal sites, had low relative abundance, which coincides with the occasional manatee occurrence reported by Colmenero and Hoz (1986). González River, located outside PCRB, is the most coastal location of this study. Previous studies considered this site to be an area with occasional manatee presence (Colmenero and $\mathrm{Hoz}$ 1986) and an area with potentially high abundance due to habitat characteristics (Arriaga and Contreras 1993). Manatee abundance was lowest at this site, but local fishermen reported seeing manatees several times during the study period; however, they saw them in the main river and not in the secondary waterways we surveyed. In the case of Tabasquillo, results from interviews (Arriaga and Contreras 1993) indicated a high abundance, contrasting with our results. During the last decade, this last watercourse has suffered modifications related to the prevention of seasonal floods upriver, which may have influenced manatees to move to other areas; however, we sampled just a small portion of this watercourse. Despite our low counts at El Coco, we found manatees in all surveys. The interviews conducted by Arriaga and Contreras (1993) could reflect a high frequency of sightings instead of a high abundance.

In San José we recorded a higher number of sightings compared to sites further north, and Bitzales River was the site with the highest abundance; this represents an increase in abundance towards the south in the PCBR. Although previous interview-based studies reported the presence of manatees in the southern part of the reserve (Colmenero and $\mathrm{Hoz}$ 1986, Arriaga and Contreras 1993), there is no mention of a high abundance in this zone. In San Pedro we registered abundances comparable with those of San José and Bitzales. Several important areas for manatee distribution have been reported to the south of the reserve (Álvarez et al. 1988, Colmenero and Hoz 1986, Rodas-Trejo et al. 2008). secundarios donde se realizaron los recorridos. En el caso de Tabasquillo, los resultados de entrevistas reportados por Arriaga y Contreras (1993) indicaron una alta abundancia de manatíes, lo que contrasta con el presente estudio. En la última década, Tabasquillo ha sufrido modificaciones que se relacionan con la prevención de inundaciones estacionales río arriba, lo que pudo haber causado que los manatíes se movieran a otros sitios; sin embargo, durante el estudio sólo se recorrió una parte menor de este curso de agua. En El Coco, a pesar de los bajos conteos obtenidos, se encontraron manatíes en todos los recorridos. Los resultados de las entrevistas de Arriaga y Contreras (1993) pueden reflejar una alta frecuencia de avistamientos en vez de una alta abundancia.

Comparado con sitios más al norte, San José presentó un alto número de avistamientos y el río Bitzales fue el sitio con mayor abundancia; esto representa un incremento de la abundancia hacia el sur de la RBPC. Aunque los estudios previos reportan la presencia de manatíes al sur de la reserva (Colmenero y Hoz 1986, Arriaga y Contreras 1993), no mencionan una alta abundancia. En San Pedro, las abundancias registradas en el presente estudio fueron comparables a las de San José y Bitzales. Más hacia el sur, fuera de la reserva, se encuentran varias áreas reportadas como importantes para los manatíes (Álvarez et al. 1988, Colmenero y Hoz 1986, Rodas-Trejo et al. 2008).

La complejidad de los sistemas de agua dulce es importante para la presencia y abundancia de manatíes en el área, pues brindan diferentes características y condiciones del hábitat. Las lagunas de tamaño medio y canales intrincados aseguran aguas calmadas y abundante vegetación. En Belice, Auil (2004) encontró manatíes en aguas interiores de canales que se conectan con lagunas. En Bitzales, los manatíes que se avistaron fuera de los transectos estuvieron en o cerca de una confluencia de un canal que lleva a una laguna. Jiménez (2005) y Jiménez-Domínguez y Olivera-Gómez (2014) resaltaron la importancia de las confluencias como características relacionadas con una mayor presencia y abundancia de manatíes. 
The complexity of freshwater systems is important for the presence and abundance of manatees in the area, providing different habitat characteristics and conditions. Medium-size lagoons and intricate channels assure calm water and vegetation. In Belize, Auil (2004) found manatees inland in streams that connect to lakes. In Bitzales, the manatees sighted outside the transects were in a confluence of a channel that connects to a lagoon. Jiménez (2005) and JiménezDomínguez and Olivera-Gómez (2014) highlighted confluences as features related to a higher presence and abundance of manatees.

We recorded manatees at all the sampled sites, confirming their regional presence as reported by Colmenero and Hoz (1986). Compared with other deltaic systems in the southern Gulf of Mexico, like the Alvarado Lagoon System in Veracruz (Daniel-Rentería et al. 2012), the study area represents an important manatee hotspot. Based on our results, PCBR is strategically located in the region; therefore, it plays an important role in manatee conservation in Mexico. A corridor should be established beyond the southern limit of the reserve to protect manatees.

Side-scan sonar is a promising tool for monitoring manatees in the southern Gulf of Mexico where water conditions preclude the use of aerial surveys or visual boat surveys. In our study we missed about $20 \%$ of manatees available for counting. Standardizing procedures among sites and areas will provide spatial distribution data on which to base conservation strategies. This sonar has been used in Mexico and abroad, but a lack of standardized procedures hinders comparisons among studies. For example, Pérez-Garduza (2013) estimated a higher density of manatees in Laguna de las Ilusiones, Tabasco, than that found in our study, but his transects were shorter $(1.9 \mathrm{~km})$ in a lake with a landlocked population of more than 20 animals. Moreover, the behavior of manatees changed in open areas compared to tight watercourses; manatees moved away from the transect instead of remaining at the bottom, which changed the estimated width of the transect surveyed. Likewise, Arévalo-González et al. (2014) surveyed a short transect over a small area with a dense number of manatees, which precludes comparison. Other studies have used sonar for the nonsystematic search of manatees with the goal of exploring new areas and not with the objective of comparing with other surveys (Brice 2014, Daniel-Rentería et al. 2012, Rodas-Trejo et al. 2008).

Factors like the presence of other large animals (e.g., crocodiles, sharks or large fish) could yield misleading counts, so it is important to evaluate if they are common in the area. While not the case in our study area, other vertebrates with important acoustic behaviors, like pinnipeds and cetaceans (Hastiea et al. 2013), may be disturbed by this method and the side-scan sonar should be used with care. Bottom type may also produce a higher perception bias in the case of large coverage of rocks or submerged vegetation; previous exploration of the area is important before considering the use of sonar.

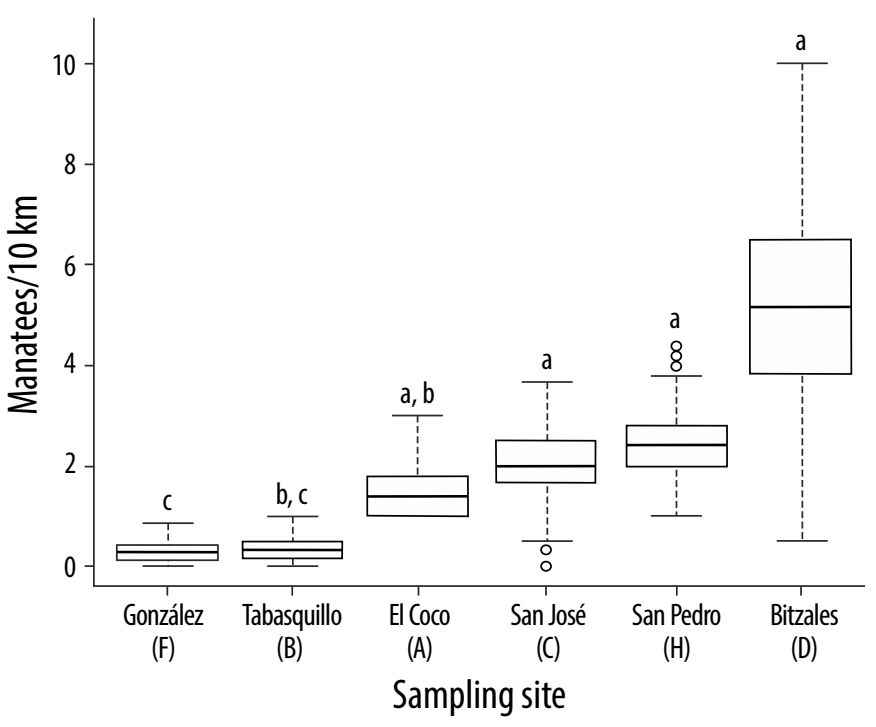

Figure 3. Distribution of manatees counted at each site surveyed in the central and eastern portions of Tabasco, Mexico (median, inter-quartile range, and range; all estimated using 10,000 bootstrap samples). Sites A to D are within the Pantanos de Centla Biosphere Reserve; $\mathrm{F}$ and $\mathrm{H}$ are reference sites to the northwest and southeast of the reserve. Lower-case letters indicate statistical groups after a post hoc analysis.

Figura 3. Distribución de los conteos de manatíes en cada uno de los sitios del estudio en las porciones central y oriental de Tabasco, México (mediana, rango intercuartílico y rango; todas las estimaciones se hicieron con 10,000 muestras bootstrap). Los sitios A-D se encuentran dentro de la Reserva de la Biosfera de Pantanos de Centla; los sitios F y $\mathrm{H}$ son sitios de referencia al noroeste y al sureste de la reserva. Las letras pequeñas indican grupos estadísticos después del procedimiento de comparaciones múltiples.

Se registraron manatíes en todos los sitios de muestreo, lo cual confirma la presencia regional de esta especie reportada por Colmenero y Hoz (1986). Comparada con otros sistemas deltaicos en el sur del golfo de México, como el sistema lagunar de Alvarado en Veracruz (Daniel-Rentería et al. 2012), el área de estudio representa un área importante de distribución. Con base en nuestros resultados, la RBPC está estratégicamente localizada en la región; por lo tanto, juega un papel importante en la conservación de la especie en México. Más allá del límite sureste de la reserva, se debería establecer un corredor para proteger a los manatíes.

El sonar de barrido lateral es una herramienta promisoria para el monitoreo de los manatíes en el sur del golfo de México donde las condiciones del agua no favorecen el uso de reconocimientos aéreos o las observaciones visuales directas desde una lancha. En nuestro estudio encontramos que no se detectó aproximadamente un $20 \%$ de los manatíes disponibles para el conteo. Los procedimientos estandarizados entre sitios y áreas pueden proveer una visión de la distribución espacial para orientar estrategias hacia la conservación. El uso del sonar se ha comenzado a implementar en otras 


\section{ACKNOWLEDGMENTS}

The Cleveland Zoological Society/Cleveland Metroparks Zoo provided funds for this study through the Scott Neotropical Fund. The directive of the Pantanos de Centla Biosphere Reserve of the National Commission for Natural Protected Areas (CONANP, Mexico) authorized the work within this protected area. We also thank the reserve guides, community members, and park rangers for their help during the field work.

\section{REFERENCES}

Álvarez-Flores C, Aguayo-Lobo A, Johnson L. 1988. Observaciones sobre el manatí Trichechus manatus en la región media del Usumacinta, Tabasco. In: Chávez-Lomelí MO (ed.), Memorias del Simposio Ecología de los Ríos Usumacinta y Grijalva, Instituto Nacional de Investigación sobre Recursos Bióticos, División Regional Tabasco y Gobierno del Estado de Tabasco, Villahermosa, México, pp. 617-624.

Aragones LV, LaCommare KS, Kendall S, Castelblanco-Martínez N, González-Socoloske D. 2012. Boat and land base surveys for sirenians. In: Hines H, Reynolds JE III, Aragones LV, MignucciGiannoni A, Marmontel M (eds.), Sirenian Conservation, Issues and Strategies in Developing Countries. University Press of Florida, Gainesville, FL, pp. 179-185.

Arévalo-González GK, Castelblanco-Martínez DN, SánchezPalomino P, Lopez-Arévalo HF, Marmontel M. 2014. Complementary methods to estimate population size of Antillean manatees (Sirenia: Tricheachidae) at Cienaga de Paredes, Santander, Colombia. J. Threat. Taxa 6: 5830-5837.

Arriaga S, Contreras W. 1993. El manatí (Trichechus manatus) en Tabasco. Informe Técnico. Universidad Juárez Autónoma de Tabasco, División Académica de Ciencias Biológicas, Villahermosa, Tabasco, 75 pp.

Auil N. 2004. Abundance and distribution trends of the West Indian manatee in the coastal zone of Belize: Implications for conservation. MSc thesis, Department of Wildlife and Fisheries Sciences, Texas A\&M University, USA, 83 pp.

Brice CE. 2014. The detection of Amazonian manatees (Trichechus inunguis) using side-scan sonar and the effect of oil activities on their habitats in eastern Ecuador. MSc thesis, Nova Southeastern University. Consulted October 182016 in: http:// nsuworks.nova.edu/occ_stuetd/8.

Colmenero LC, Hoz ME. 1986. Distribución de los manatíes, situación y su conservación en México. An. Inst. Biol., Univ. Nac. Aut. Méx. Ser. Zool. 3: 955-1020.

[CONANP] Comisión Nacional de Áreas Naturales Protegidas. 2001. Programa de Conservación y Manejo de la Reserva de la Biósfera Pantanos de Centla. CONANP, Serie Didáctica, Ciudad de México, 21 pp.

Daniel-Rentería IC, Serrano A, Sánchez-Rojas G. 2012. Distribution of the Antillean manatee (Trichechus manatus manatus) in the Alvarado Lagoon System (Veracruz, Mexico) = Distribución del manatí antillano (Trichechus manatus manatus) en el Sistema Lagunar de Alvarado (Veracruz, México). Cienc. Mar. 38(2): 459-465. http://dx.doi.org/10.7773/cm.v38i2.2062

Deutsch CJ, Self-Sullivan C, Mignucci-Giannoni A. 2008. Trichechus manatus. The IUCN Red List of Threatened Species 2008: e.T22103A9356917 [cited 17 November 2016]. http://dx.doi.org/10.2305/IUCN.UK.2008.RLTS.T22103A9356917.en regiones, tanto en México como en el extranjero, pero la falta de estandarización en el método dificulta las comparaciones. Por ejemplo, Pérez-Garduza (2013) estimó densidades de manatíes que fueron mucho más altas en la laguna de las Ilusiones, Tabasco, que las encontradas en este estudio, pero sus navegaciones fueron más cortas $(1.9 \mathrm{~km})$ y en un área con una población importante de manatíes. Además, la conducta de los manatíes parece ser distinta en áreas abiertas que en cursos de agua estrechos; los manatíes se apartan del transecto en vez de quedarse en el fondo, lo que cambia el ancho estimado del transecto. En el trabajo de Arévalo-González et al. (2014) los transectos también fueron muy cortos y sobre un área de congregación de animales, por lo que las densidades no son comparables. Otros trabajos han utilizado el sonar para la búsqueda no sistemática de manatíes con propósitos de exploración de nuevas áreas y no con el fin de obtener resultados comparativos entre áreas (Brice 2014, DanielRentería et al. 2012, Rodas-Trejo et al. 2008).

Factores como la presencia de otros animales de tamaño mediano o grande (e.g., cocodrilos, tiburones o peces grandes) pueden ocasionar errores de conteo, por lo que habría que evaluar si su presencia es importante en el área. Otros vertebrados con hábitos acústicos importantes como pinnípedos o cetáceos (Hastiea et al. 2013), que no están presentes en el área de estudio, pueden ser perturbados con este método, por lo que el sonar debe usarse cuidadosamente. El tipo de fondo también podría ocasionar un mayor sesgo en la percepción en caso de una cobertura extensa de plantas sumergidas o fondos rocosos; en todo caso, una exploración previa es importante antes de implementar un monitoreo con el sonar.

\section{Agradecimientos}

La Sociedad Zoológica de Cleveland y el Cleveland Metroparks Zoo proveyeron los fondos para este estudio a través del Scott Neotropical Fund. La dirección de la Reserva de la Biosfera de Pantanos de Centla de la Comisión Nacional de Áreas Naturales Protegidas (CONANP) autorizó el trabajo dentro del área natural protegida. Queremos agradecer a los guías de campo, miembros de la comunidad y a los guardaparques de la reserva el apoyo brindado durante el trabajo de campo.

Good PI. 2006. Resampling Methods: A Practical Guide to Data Analysis. 3rd ed. Birkhauser, Boston, MA 218 pp.

González-Socoloske D, Olivera-Gomez LD. 2012. Gentle giants in dark waters: Using side-scan sonar for manatee research. Open Rem. Sens. J. 5(1): 1-14. http://dx.doi.org/10.2174/1875413901205010001

Gonzalez-Socoloske D, Olivera-Gomez LD, Ford RE. 2009. Detection of free-ranging West Indian manatees (Trichechus manatus) with side-scan sonar. Endang. Species Res. 8(3): 249-257.

http://dx.doi.org/10.3354/esr00232 
Guadarrama-Olivera MA, Ortiz-Gil G. 2000. Análisis de la flora de la Reserva de la Biósfera de los Pantanos de Centla, Tabasco, México. Univ. Cienc. 15: 67-104.

Hastiea GD, Donovan C, Götz T, Janik VM. 2013. Behavioral responses by grey seals (Halichoerus grypus) to high frequency sonar. Mar. Pollut. Bull. 79(1-2): 205-210.

http://dx.doi.org/10.1016/j.marpolbul.2013.12.013

[INE] Instituto Nacional de Ecología. 2000. Programa de Manejo Reserva de la Biósfera Pantanos de Centla, México. Instituto Nacional de Ecología [cited 6 June 2016], Ciudad de México, 222 pp. Available from: http://www.inecc.gob.mx/descargas/ publicaciones/179.pdf.

[INEGI] Instituto Nacional de Estadística y Geografía. 2011. Perspectiva Estadística Tabasco 2011. Instituto Nacional de Estadística Geografía e Informática, Dirección General de Geografía y Medio Ambiente [cited 6 June 2016], Ciudad de México, 92 pp. Available from: http://www.inegi.gob.mx/est/ contenidos/espanol/sistemas/perspectivas/perspectiva-tab.pdf.

Jiménez I. 2005. Development of predictive models to explain the distribution of the West Indian manatee Trichechus manatus in tropical watercourses. Biol. Conserv. 125(4): 491-503. http://dx.doi.org/10.1016/j.biocon.2005.04.012

Jiménez-Domínguez D, Olivera-Gómez LD. 2014. Características del hábitat del manatí antillano (Trichechus manatus manatus) en sistemas fluviolagunares del sur del Golfo de México. Therya 5(2): 601-614. http://dx.doi.org/10.12933/therya-14-205

Lefebvre LW, Marmontel M, Reid JP, Rathbun GB, Domning DP. 2001. Status and biogeography of the West-Indian manatee. In: Woods C, Sergile FE (eds.), Biogeography of the West Indies: Past, Present, and Future. 2nd ed. CRC Press, Boca Raton, FL, pp. 425-474.

Marsh H, Sinclair DF. 1989. Correcting for visibility bias in strip transect aerial survey for aquatic fauna. J. Wildl. Manage. 53(4): 1017-1024. http://dx.doi.org/10.2307/3809604

Marsh H, O’Shea TJ, Reynolds JE III. 2012. Ecology and Conservation of the Sirenia: Dugongs and Manatees. Cambridge University Press, Cambridge, 521 pp.

Morales-Vela B, Olivera-Gómez LD, Reynolds JE III, Rathbun GB. 2000. Distribution and habitat use by manatees (Trichechus manatus manatus) in Belize and Chetumal Bay, Mexico. Biol. Conserv. 95(1): 67-75. http://dx.doi.org/10.1016/S0006-3207(00)00009-4
Moreno-Casasola P, Infante-Mata D, López-Rosas H. 2012. Tropical freshwater swamps and marshes. In: Batzer DP, Baldwin AH (eds.), Wetland Habitat of North America, Ecology and Conservation Concerns. University of California Press, Berkeley and Los Angeles, CA, pp. 267-282.

Novelo A, Ramos L. 2005. Vegetación acuática. In: Bueno J, Álvarez F, Santiago S (eds.), Biodiversidad del Estado de Tabasco. Instituto de Biología, UNAM-CONABIO, Ciudad de México, pp. 111-144.

Pablo-Rodríguez N, Olivera-Gómez LD. 2012. Situación de una población aislada de manatíes Trichechus manatus (Mammalia: Sirenia: Trichechidae) y conocimiento de la gente, en una laguna urbana, en Tabasco, México. Univ. Cienc. 28: 15-26.

Pérez-Garduza F. 2013. Evaluación de la eficiencia de cinco técnicas para determinar la abundancia de manatíes Trichechus manatus en ambientes poco visibles. MSc thesis, Universidad Juárez Autónoma de Tabasco, México, 45 pp.

Reynolds JE III, Morales-Vela B, Lawler I, Edwards H. 2012. Utility and design of aerial surveys for manatees. In: Hines $\mathrm{H}$, Reynolds JE, Aragones LV, Mignucci-Giannoni A, Marmontel $M$ (eds.), Sirenian Conservation, Issues and Strategies in Developing Countries. University Press of Florida, Gainesville, FL, pp. 186-195.

Rodas-Trejo J, Romero-Berny EI, Estrada A. 2008. Distribution and conservation of the West Indian manatee (Trichechus manatus manatus) in the Catazajá wetlands of northeast Chiapas, Mexico. Trop. Conserv. Sci. 4: 321-333.

Romero GJ, García MA, Bautista JA, Pérez APH. 2000. Caracterización de la Reserva de la Biósfera Pantanos de Centla. Univ. Cienc. 15: 15-20.

Self-Sullivan C, Mignucci-Giannoni A. 2008. Trichechus manatus ssp. manatus. The IUCN Red List of Threatened Species 2008 [cited 17 September 2015]. Available from: http://dx.doi.org/ 10.2305/IUCN.UK.2008.RLTS.T22105A9359161.en.

Siegel S, Castellan NJ. 1995. Estadística No Paramétrica Aplicada a las Ciencias de la Conducta. 4th ed. Editorial Trillas, Ciudad de México.

Zenteno CE, Macías EB, Bello-Gutiérrez J, Ochoa-Gaona S. 2010. Caracterización del hábitat de Dermatemys mawii (Testudines: Dermatemydidae) en la cuenca del Grijalva-Usumacinta, Tabasco, México. Rev. Biol. Trop. 58: 1247-1260.

Received September 2016, accepted November 2016. 